\title{
An In Vitro Germination Technique for Some Stone Fruit Species: the Embryo Isolated from Cotyledons Successfully Germinated without Cold Pre-treatment of Seeds
}

\author{
Bekir Şan', Adnan Nurhan Yildirim, and Fatma Yildirim \\ Suleyman Demirel University, Faculty of Agriculture, Department of \\ Horticulture, 32260 Isparta, Turkey
}

Additional index words. 6-benzylaminopurine, apricot, gibberellic acid, in vitro germination, peach, wild cherry

\begin{abstract}
Seeds of temperate fruit species need a long time to germinate as a result of their requirement of stratification or cold treatment. Therefore, fast and uniform germination techniques are desirable and important for fruit tree propagation and especially for breeding studies. The effects of combinations of benzylaminopurine (BAP) and gibberellic acid $\left(\mathrm{GA}_{3}\right)$ on in vitro embryo germination of apricot, peach, and wild cherry were determined without seed cold pretreatment. The results showed that no germination was recorded in all the seeds with testa. In the seeds without testa, no germination (wild cherry) or limited germination (less than $10 \%$ ) was recorded. When the embryos separated from cotyledons were cultured, successful germination was obtained for all species. In general, the addition of different combinations of $\mathrm{BAP}$ and $\mathrm{GA}_{3}$ into the Murashige and Skoog (MS) medium significantly increased the germination ratios of embryos without cotyledons in all species. For wild cherry, the best treatment $(66.7 \%$ germination) was MS media containing $0.5 \mathrm{mg} \cdot \mathrm{L}^{-1} \mathrm{BAP}+2.0 \mathrm{mg} \cdot \mathrm{L}^{-1} \mathrm{GA}_{3}$ or $0.5 \mathrm{mg} \cdot \mathrm{L}^{-1}$ BAP $+4.0 \mathrm{mg} \cdot \mathrm{L}^{-1} \mathrm{GA}_{3}$. For peach, the best treatment $(86.7 \%$ germination $)$ was $\mathrm{MS}$ medium supplemented with $0.5 \mathrm{mg} \cdot \mathrm{L}^{-1} \mathrm{BAP}+3.0 \mathrm{mg} \cdot \mathrm{L}^{-1} \mathbf{G A}_{3}$. For apricot, the best treatment $(93.3 \%)$ was $\mathrm{MS}$ media containing $0.5 \mathrm{mg} \cdot \mathrm{L}^{-1} \mathrm{BAP}+3.0 \mathrm{mg} \cdot \mathrm{L}^{-1} \mathrm{GA}_{3}$, $1.0 \mathrm{mg} \cdot \mathrm{L}^{-1} \mathrm{BAP}+1.0 \mathrm{mg} \cdot \mathrm{L}^{-1} \mathrm{GA}_{3}$, or $1.0 \mathrm{mg} \cdot \mathrm{L}^{-1} \mathrm{BAP}+2.0 \mathrm{mg} \cdot \mathrm{L}^{-1} \mathrm{GA}_{3}$.
\end{abstract}

Seeds of temperate fruit species do not germinate as a result of seed dormancy even if conditions such as water, temperature, and oxygen are suitable for germination. Seed dormancy is classified as physiological, morphological, morpho-physiological, physical, and combinational dormancy (physical and physiological) (Baskin and Baskin, 1997, 2004; Finch-Savage and Leubner-Metzger, 2006). These mechanisms of dormancy are present in the seeds of all temperature fruit species, including peach, cherry, and apricot (Han et al., 2002; Martinez-Gomez and Dicenta, 2001). On the other hand, some chemicals such as abscissic acid (ABA), coumarin, and jasmonates could also impose seed dormancy (Bewley, 1997; Linkies and Leubner-Metzger, 2012). Moreover, other substances such as phenolics could prevent seed germination (Yukiko et al., 2001). The germination inhibitors exist at different concentrations in various parts of a seed, including pericarp, seedcoat, cotyledons, and embryo. The proportion of inhibitors could be decreased by removing either one or several

Received for publication 26 Nov. 2013. Accepted for publication 23 Jan. 2014.

${ }^{1}$ To whom reprint requests should be addressed; e-mail bekirsan@sdu.edu.tr, sanbekir@gmail.com. from cotyledons until now (Arbeloa et al., 2009; San and Yildirim, 2009), although there are some studies on in vitro germination of whole embryo.

The objective of the present study was to determine the effects of isolating embryo from cotyledons and the combination of BAP $\left(0,0.5\right.$, and $\left.1.0 \mathrm{mg} \cdot \mathrm{L}^{-1}\right)$ with $\mathrm{GA}_{3}(0,1.0$, $\left.2.0,3.0,4.0 \mathrm{mg} \cdot \mathrm{L}^{-1}\right)$ on the in vitro germination of apricot, peach, and wild cherry without cold treatment.

\section{Materials and Methods}

Seeds from apricot (Prunus armeniaca $\mathrm{L}$. cv. Alyanak), peach (Prunus persica L. cv. Redhaven), and wild cherry (synonym: bird cherry) (Prunus avium L.) fruits collected in the same year were used as material in the study. The maturation time of apricot cultivar Alyanak, a midseason cultivar (Uslu et al., 1996), is 15 to 25 June in the Isparta region of Turkey. The maturation time of peach cultivar Redhaven, a midseason cultivar, is 1 to 5 Aug. in the Isparta region of Turkey (Akgul et al., 2005). Wild cherry fruits were harvested from a tree in the first week of July in Isparta region of Turkey. Seeds isolated from mature fruits were dried at room temperature for $30 \mathrm{~d}$ before they were used. After cracking the shells by hand, the seeds were removed from the shells (Fig. 1A-B) and pre-sterilized by immersion into $3.75 \%(\mathrm{v} / \mathrm{v})$ sodium hypochlorite solution containing two to three drops of Tween 20 (Merck KGaA, Darmstadt, Germany) for $25 \mathrm{~min}$ followed by rinsing three times for $5 \mathrm{~min}$ in sterile distilled water. Then, sterilized seeds were incubated in sterile distilled water for $60 \mathrm{~h}$ for easy removal of testa by replacing the water every $\approx 12 \mathrm{~h}$. Turgid seeds were sterilized again as described previously (San and Yildirim, 2009). After the testa (seedcoat) was removed, seeds with/without testa were cultured in petri dishes $(100 \times 10 \mathrm{~mm})$ on MS medium (Murashige and Skoog, 1962) containing no plant growth regulators. Three percent $(\mathrm{w} / \mathrm{v})$ sucrose (Merck KGaA) and $0.7 \%(\mathrm{w} / \mathrm{v}$ ) agar (Oxoid; Thermo Fisher Scientific Inc.) were added to the MS medium. After $\mathrm{pH}$ was adjusted to 5.7 with potassium hydroxide $(\mathrm{KOH})$ and hydrochloric acid $(\mathrm{HCl})$, the medium was autoclaved at $121^{\circ} \mathrm{C}$ for $15 \mathrm{~min}$ and distributed to the petri dishes under sterile conditions. Because the whole embryos (seeds) with/without testa (Fig. 1B-C) did not germinate, embryos isolated from cotyledons were cultured on MS medium containing different combination of plant growth regulators (Fig. 1D-E).

To determine the best combination of plant growth regulators for in vitro embryo germination, the embryos were carefully excised from the cotyledons under sterile conditions and were cultured on MS medium supplemented with BAP (Merck KGaA) and $\mathrm{GA}_{3}$ (Merck KGaA) in the quantities as shown in Table 1. Three percent (w/v) sucrose (Merck $\mathrm{KGaA}$ ) and $0.7 \%(\mathrm{w} / \mathrm{v})$ agar (Oxoid; Thermo Fisher Scientific Inc.) were added into the MS medium. After the $\mathrm{pH}$ was adjusted to 5.7 with 
$\mathrm{KOH}$ and $\mathrm{HCl}$, the medium was autoclaved at $121{ }^{\circ} \mathrm{C}$ for $15 \mathrm{~min}$ and distributed to the petri dishes under sterile conditions. Filtersterilized $\mathrm{GA}_{3}$ doses were added to media cooled to $\approx 50{ }^{\circ} \mathrm{C}$ after autoclaving.

Cultures were incubated in a growth chamber at $25 \pm 1{ }^{\circ} \mathrm{C}$ under a 16 -h photoperiod provided by cool white fluorescent lamps ( 140 to $\left.150 \mu \mathrm{mol} \cdot \mathrm{m}^{-2} \cdot \mathrm{s}^{-1}\right)$ for 3 weeks in both the whole embryos with/without testa and embryos isolated from cotyledons. The germination percentages were recorded at the end of 3 weeks. Each treatment consisted of three replications and each replication contained four petri dishes with five explants per petri dish.

Data were subjected to analysis of variance using Minitab software (MINITAB Inc.). Duncan's multiple range test was applied to determine significant differences between the means $(P \leq 0.05)$. An arcsin transformation was performed to stabilize the variance of percent germination values and angle values were used in the analysis of variance. The real values obtained from the research were presented in the Table 1.

\section{Results and Discussion}

Table 1 shows the germination percentages of seeds and isolated embryos obtained from the MS media containing different concentrations of BAP and $\mathrm{GA}_{3}$ in apricot, peach, and wild cherry species. Seeds with testa did not germinate on the MS medium containing no growth regulators in all species studied (Table 1; Fig. 2A). No germination was recorded in the seeds with testa. Likewise, in the seeds without testa, either no germination (wild cherry) or limited (less than $10 \%$ ) germination was shown (Table 1 ; Fig. 2B). The isolation of the embryo from testa did not significantly increase the germination ratios of the stated species. This might be the result of the presence of inhibitors in the cotyledons and/or testa (Martinez-Gomez and Dicenta, 2001; Mehanna and Martin, 1985; San and Yildirim, 2009). However, in all species, germination ratios significantly increased when embryos isolated from cotyledons were cultured on the MS medium containing no plant growth regulator.

These results highlighted that cotyledons may contain some germination inhibitors such as ABA. San and Yildirim (2009) reported that almond embryo with cotyledons did not germinate because of presence of inhibitors in cotyledons even if BAP and $\mathrm{GA}_{3}$ were added to the MS medium. Although germination ratios increased with the isolation of embryo from cotyledons, results were not satisfactory in the present study possibly as a result of the presence of inhibitors in the embryo (Bewley, 1997; Linkies and Leubner-Metzger, 2012). Therefore, we cultured the embryos (without cotyledons) of apricot, peach, and wild cherry on MS medium fortified with different combinations of growth regulators. Addition of different combinations of BAP and $\mathrm{GA}_{3}$ into the MS medium significantly increased the germination ratios of embryos of the species

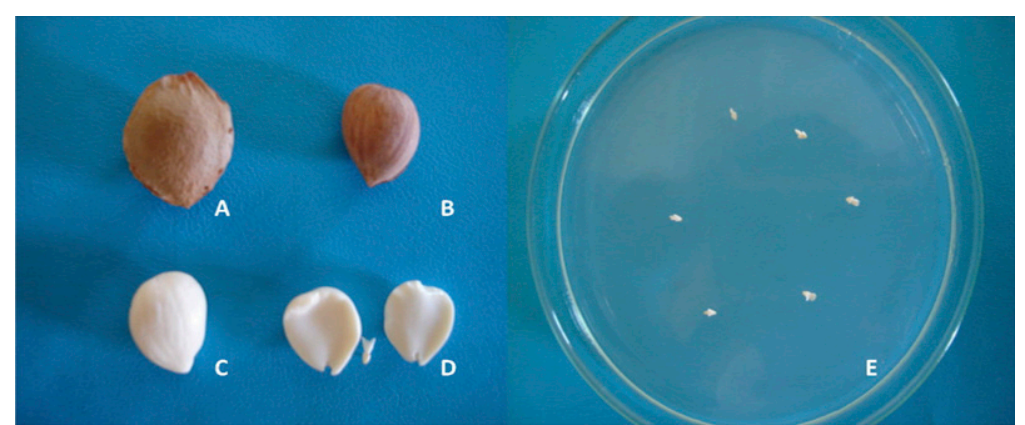

Fig. 1. Germination stages. (A) An apricot seed with shell; (B) an apricot seed isolated from shell; (C) a whole embryo isolated from shell and testa; (D) the separation of cotyledons from embryo; (E) embryos without cotyledons cultured on Murashige and Skoog medium.

Table 1. The effects of some combinations of benzylaminopurine (BAP) and gibberellic acid $\left(\mathrm{GA}_{3}\right)$ on the embryo germination in apricot, peach, and wild cherry species $(\%)$.

\begin{tabular}{|c|c|c|c|c|}
\hline Treatments & Apricot & Peach & Wild cherry & $\mathrm{Avg}$ \\
\hline \multicolumn{5}{|l|}{ Seed germination } \\
\hline Seed with testa on the MS medium ${ }^{z}$ & 0 & 0 & 0 & 0 \\
\hline Seed without testa on the MS medium ${ }^{z}$ & 5.0 & 10.0 & 0 & 5.0 \\
\hline Average & 2.5 & 5.0 & 0 & \\
\hline \multicolumn{5}{|l|}{ Embriyo germination (without cotyledons) } \\
\hline MS medium $(\text { control })^{\mathrm{z}}$ & $53.3 \mathrm{~b}^{\mathrm{y}}$ & $53.3 \mathrm{~b}$ & $33.3 \mathrm{c}$ & 46.6 \\
\hline MS medium $+0.5 \mathrm{mg} \cdot \mathrm{L}^{-1} \mathrm{BAP}+1.0 \mathrm{mg} \cdot \mathrm{L}^{-1} \mathrm{GA}_{3}$ & $80.0 \mathrm{a}$ & $53.3 \mathrm{~b}$ & $40.0 \mathrm{bc}$ & 57.8 \\
\hline $\mathrm{MS}$ medium $+0.5 \mathrm{mg} \cdot \mathrm{L}^{-1} \mathrm{BAP}+2.0 \mathrm{mg} \cdot \mathrm{L}^{-1} \mathrm{GA}_{3}$ & $80.0 \mathrm{a}$ & $73.3 \mathrm{ab}$ & $66.7 \mathrm{a}$ & 73.3 \\
\hline $\mathrm{MS}$ medium $+0.5 \mathrm{mg} \cdot \mathrm{L}^{-1} \mathrm{BAP}+3.0 \mathrm{mg} \cdot \mathrm{L}^{-1} \mathrm{GA}_{3}$ & $93.3 \mathrm{a}$ & $86.7 \mathrm{a}$ & $60.0 \mathrm{ab}$ & 80.0 \\
\hline $\mathrm{MS}$ medium $+0.5 \mathrm{mg} \cdot \mathrm{L}^{-1} \mathrm{BAP}+4.0 \mathrm{mg} \cdot \mathrm{L}^{-1} \mathrm{GA}_{3}$ & $86.7 \mathrm{a}$ & $80.0 \mathrm{a}$ & $66.7 \mathrm{a}$ & 77.8 \\
\hline MS medium $+1.0 \mathrm{mg} \cdot \mathrm{L}^{-1} \mathrm{BAP}+1.0 \mathrm{mg} \cdot \mathrm{L}^{-1} \mathrm{GA}_{3}$ & $93.3 \mathrm{a}$ & $66.7 \mathrm{ab}$ & $53.3 \mathrm{abc}$ & 71.1 \\
\hline MS medium $+1.0 \mathrm{mg} \cdot \mathrm{L}^{-1} \mathrm{BAP}+2.0 \mathrm{mg} \cdot \mathrm{L}^{-1} \mathrm{GA}_{3}$ & $93.3 \mathrm{a}$ & $53.3 \mathrm{~b}$ & $46.7 \mathrm{abc}$ & 64.4 \\
\hline MS medium $+1.0 \mathrm{mg} \cdot \mathrm{L}^{-1} \mathrm{BAP}+3.0 \mathrm{mg} \cdot \mathrm{L}^{-1} \mathrm{GA}_{3}$ & $86.7 \mathrm{a}$ & $40.0 \mathrm{~b}$ & $46.7 \mathrm{abc}$ & 57.8 \\
\hline MS medium $+1.0 \mathrm{mg} \cdot \mathrm{L}^{-1} \mathrm{BAP}+4.0 \mathrm{mg} \cdot \mathrm{L}^{-1} \mathrm{GA}_{3}$ & $73.3 \mathrm{ab}$ & $53.3 \mathrm{~b}$ & $50.0 \mathrm{abc}$ & 58.9 \\
\hline Average & 82.2 & 62.2 & 51.5 & \\
\hline
\end{tabular}

${ }^{\mathrm{z}} \mathrm{MS}$ medium without plant growth regulator was used for the in vitro germination.

${ }^{y}$ Different letters indicate significantly different means at the level of $P \leq 0.05$ in the same column. MS = Murashige and Skoog.

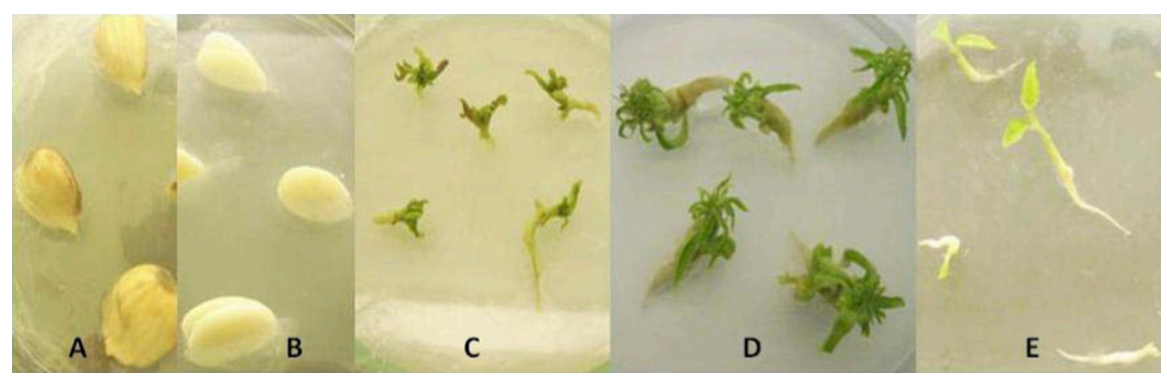

Fig. 2. In vitro seed and embryo germination in some stone fruits; (A) seed with seedcoat did not germinate on Murashige and Skoog (MS) medium; (B) seed without seedcoat did not germinate on MS medium; (C) apricot embryos (without cotyledon) successfully germinated on MS medium containing 0.5 mg. $\mathrm{L}^{-1}$ benzylaminopurine (BAP) $+3.0 \mathrm{mg} \mathrm{L}{ }^{-1}$ gibberellic acid $\left(\mathrm{GA}_{3}\right)$; (D) peach embryos (without cotyledon) successfully germinated on $\mathrm{MS}$ medium containing $0.5 \mathrm{mg} \cdot \mathrm{L}^{-1} \mathrm{BAP}+3.0 \mathrm{mg} \cdot \mathrm{L}^{-1} \mathrm{GA} \mathrm{A}_{3}$; (E) wild cherry embryos (without cotyledon) successfully germinated on MS medium containing $0.5 \mathrm{mg} \cdot \mathrm{L}^{-1} \mathrm{BAP}+2.0 \mathrm{mg} \cdot \mathrm{L}^{-1} \mathrm{GA}_{3}$.

(Table 1; Fig. 2C-E). The highest germination percentage was $93.3 \%$ on the MS media containing $0.5 \mathrm{mg} \cdot \mathrm{L}^{-1}$ BAP $+3.0 \mathrm{mg} \cdot \mathrm{L}^{-1}$ $\mathrm{GA}_{3}, 1.0 \mathrm{mg} \cdot \mathrm{L}^{-1} \mathrm{BAP}+1.0 \mathrm{mg} \cdot \mathrm{L}^{-1} \mathrm{GA}_{3}$, or $1.0 \mathrm{mg} \cdot \mathrm{L}^{-1} \mathrm{BAP}+2.0 \mathrm{mg} \cdot \mathrm{L}^{-1} \mathrm{GA}_{3}$ in apricot. However, the differences between the germination percentages obtained from MS media containing all combinations of BAP and $\mathrm{GA}_{3}$ were not statistically significant. Germination ratios of peach embryos increased to $86.7 \%$ when embryos were cultured on MS medium supplemented with $0.5 \mathrm{mg} \cdot \mathrm{L}^{-1} \mathrm{BAP}+3.0$ $\mathrm{mg} \cdot \mathrm{L}^{-1} \mathrm{GA}_{3}$. The MS media containing $0.5 \mathrm{mg} \cdot \mathrm{L}^{-1} \mathrm{BAP}+2.0 \mathrm{mg} \cdot \mathrm{L}^{-1} \mathrm{GA}_{3}$ or 0.5 $\mathrm{mg} \cdot \mathrm{L}^{-1} \mathrm{BAP}+4.0 \mathrm{mg} \cdot \mathrm{L}^{-1} \mathrm{GA}_{3}$ gave the highest germination percentage in wild cherry $(66.7 \%)$. The positive effects of BAP and $\mathrm{GA}_{3}$ on the embryo germination might be the result of their antagonistic effects to certain inhibitors such as ABA (Aygun et al., 2009; Debeaujon and Koornneef, 2000; Linkies and LeubnerMetzger, 2012). 
Seeds with cotyledons and/or testa of apricot, peach, and wild cherry did not germinate on the MS medium without cold treatment or stratification. However, seeds could be germinated successfully without cold treatment through isolation of embryos from cotyledons. In this way, the time required for obtaining plants from seeds could be shortened. For successful in vitro embryo germination, the MS medium should be fortified with $0.5 \mathrm{mg} \cdot \mathrm{L}^{-1} \mathrm{BAP}+3.0 \mathrm{mg} \cdot \mathrm{L}^{-1} \mathrm{GA}_{3}$ in apricot, peach, and wild cherry.

\section{Literature Cited}

Akgul, H., E.M. Dolunay, S. Ozongun, S. Ozyigit, A. Atasay, I. Demirtas, M. Pektas, G. Ozturk, O.F. Karamursel, Y. Sesli, A. Goktas, I. Gur, H.C. Sarısu, and Z. Karaarslan. 2005. The catalog of fruit cultivars. Publications of Fruit Growing Research Station, No. 12, Isparta, Turkey.

Arbeloa, A., M.E. Daorden, E. Garcia, P. Andreu, and J.A. Marin. 2009. In vitro culture of 'Myrobalan' (Prunus cerasifera Ehrh.) embryos. HortScience 44:1672-1674.

Aygun, A., V. Erdogan, and E. Bozkurt. 2009. Effect of some pretreatments on seed germination of Turkish hazel (Corylus colurna L.). Acta Hort. 845:203-206.

Baskin, J.M. and C.C. Baskin. 1997. Methods of breaking seed dormancy in the endangered species Iliamna corei (Sherff) Sherff (Malvaceae), with special attention to heating. Nat. Areas J. 17:313-323.

Baskin, J.M. and C.C. Baskin. 2004. A classification system for seed dormancy. Seed Sci. Res. 14:1-16.
Bewley, J.D. 1997. Seed germination and dormancy. Plant Cell 9:1055-1066.

Bridgen, M.P. 1994. A review of plant embryo culture. HortScience 29:1243-1246.

Debeaujon, I. and M. Koornneef. 2000. Gibberellin requirement for Arabidopsis seed germination is determined both by testa characteristics and embryonic abscisic acid. Plant Physiol. 122: 415-424.

Finch-Savage, W.E. and G. Leubner-Metzger. 2006 Seed dormancy and the control of germination. New Phytol. 171:501-523.

Han, M., M. Zhang, Y. Tian, W. Zhang, and J. Zhang. 2002. Effect of plant hormones on seed dormancy and seedling growth of stone fruits. Acta Botanica Boreali-Occidentalia Sinica 22:1348-1354 (abstract).

Hassanein, A.M. and M.M. Azooz. 2003. Propagation of Citrus reticulata via in vitro seed germination and shoot cuttings. Biol. Plant. 47:173-177.

Hormaza, J.I. 1999. Early selection in cherry combining RAPDs with embryo culture. Sci. Hort. 79:121-126.

Kaur, R., N. Sharma, K. Kumar, D.R. Sharma, and S.D. Sharma. 2006. In vitro germination of walnut (Juglans regia L.) embryos. Sci. Hort. 109:385-388.

Ledbetter, C.A., D.A. Palmquist, and S.J. Peterson 1998. Germination and net in vitro growth of peach, almond, and peach-almond hybrid embryos in response to mannitol inclusion in the nutrient medium. Euphytica 103:243-250.

Linkies, A. and G. Leubner-Metzger. 2012. Beyond gibberellins and abscisic acid: How ethylene and jasmonates control seed germination. Plant Cell Rep. 31:253-270.

Martinez-Gomez, P. and F. Dicenta. 2001. Mechanisms of dormancy in seeds of peach [Prunus persica (L.) Batsch] cv. GF305. Sci. Hort. 91:51-58.

Mehanna, H.T. and G.C. Martin. 1985. Effect of seed coat on peach seed germination. Sci. Hort. $25: 247-254$

Miller, A.R., J.C. Scheereus, P.S. Erb, and C.K. Chandler. 1992. Enhanced strawberry seed germination through in vitro culture of cut achenes. J. Amer. Soc. Hort. Sci. 117:313-316.

Murashige, T. and F. Skoog. 1962. A revised medium for rapid growth and bioassay with tobacco tissue cultures. Physiol. Plant. 15:473497.

Nicolas, C., G. Nicolas, and D. Rodriguez. 1996. Antagonistic effects of abscisic acid and gibberellic acid on the breaking of dormancy of Fagus sylvatica seeds. Physiol. Plant. 96:244250 .

Ning, G.G., S.P. Bai, M.Z. Bao, and L. Liu. 2007. Factors affecting plantlet regeneration from in vitro cultured immature embryos and cotyledons of Prunus mume 'Xue mei'. In Vitro Cell. Dev. Biol. Plant 43:225-230.

San, B. and A.N. Yildirim. 2009. Seed and in vitro embryo germination in aged almond. Seed Sci. and Technol. 37:365-371.

Soyler, D. and K.M. Khawar. 2007. Seed germination of caper (Capparis ovata var. Herbacea) using $\alpha$ naphthalene acetic acid and gibberellic acid. Intl. J. of Agr. and Biol. 9:35-37.

Uslu, S., U. Guloglu, and S. Mutlu. 1996. The catalog of apricot cultivars. Publications of The Ministry of Agriculture and Forestry, Ankara, Turkey.

Yukiko, I., K. Yasuo, and T. Minoru. 2001. Effects of phenolic compounds on seed germination of shirakamba birch, Betula platyphylla var. japonica. Eurasian J. of Forest Res. 2:17-25. 